\title{
Yaprak Senesensi: Fizyolojik ve Moleküler Düzenlenmesine Bakış
}

\author{
Nihal Gören SAĞLAM \\ İstanbul Üniversitesi, Fen Fakültesi, Biyoloji Bölümü, Botanik Anabilimdal, Süleymaniye, İstanbul
}

\begin{abstract}
ÖZET
Bitkilerde görülen, tüm bitki, organ, doku ya da hücre ölümü ile sonuçlanan önemli bir gelişme süreci olan senesens ile ilgili çalışmalar 1800’lü yılların sonlarına dayanmaktadır. İlk yıllarda gözlemlerden oluşan bu çalışmalar, günümüzde teknolojinin ve genetik biliminin gelişmesiyle yerini kapsamlı biyoteknolojik araştırmalara bırakmıştır. Dünyanın çeşitli yerlerindeki araştırma merkezlerinde bilim adamları senesensin genetik mekanizmasının aydınlatılması ile ilgili deneyler yapmaktadırlar. Üzerinde en çok araştırma yapılan senesens çeşidi, yapraklarda görülen ve klorofil kaybı ile karakterize edilen yaprak senesensidir. Senesens mekanizmasının aydınlatılması ekonomik düzeyde ürün kalitesinin artırılmasında, maydanoz, brokoli, ıspanak gibi sebze, domates, elma gibi meyve ve karanfil, Alstroemeria, petunya gibi süs bitkilerinin raf ömrünün uzatılmasında büyük yararlar sağlayacaktır. Bu derlemede yaprak senesensinin fizyolojik ve moleküler düzenlenme mekanizmaları anlatılmıştır.
\end{abstract}

Anahtar kelimeler: Yaprak senesensi, klorofil kaybı, genetik mekanizma, fizyolojik düzenlenme

\section{Leaf Senescence: A View of Its Physiological and Molecular Regulation}

\begin{abstract}
Studies related to senescence, which is an important developmental process in plants and leads to death of a cell, tissue or whole plant, is based on the end of the 1800s. The preliminary studies were at observational level but they were replaced by comprehensive biotechnological research in conjunction with the development of technology and genetic science. The scientists in various part of the world have carried out experiments related to elucidation of the genetic mechanism of senescence. Leaf senescence is one of the most studied types occurred in leaf and characterized by loss of chlorophyll. Elucidation of the mechanism of senescence will provide great economic benefits in improving product quality and extending the shelf life of vegetables such as parsley, broccoli, spinach and fruit such as tomato, apple and ornamental plants such as carnation, alstroemeria, petunia. In this review, regulatory mechanisms of leaf senescence were discussed.
\end{abstract}

Keywords: Leaf senescence, loss of chlorophyll, genetic mechanism, physiological regulation

\section{GíRiş}

Senesens yaşa bağlı olarak hücre, doku, organ ve organizma düzeyinde ölümle ya da yaşam döngüsünün sona ermesiyle sonuçlanan bitki gelişimindeki son evredir [1,2,3,4]. Azot, kükürt, fosfor ve potasyum gibi önemli besinlerin taşınması ve geri dönüşümü açısından bir bitkinin gelişiminde senesens hayati önem taşımaktadır. $\mathrm{Bu}$ besinler senesens olan yapraklardan aktif olarak büyüyen dokulara taşınır, böylece bitkinin büyümesi ve çoğalması desteklenmiş olur $[3,4]$. Bazı araştırıcılar senesensin, elverişsiz çevre koşulları (kuraklık, sıcaklık, azot eksikliği, yetersiz 1ş1k, hastalık ve patojen saldırılar) sonucunda meydana gelmesinin [5] yanında, en uygun büyüme koşullarında yetişen sağlıklı bitkilerde de genetik olarak meydana geldiğini bildirmişlerdir [6,7]. Bir hücrenin yaşamsal geçmişi mitotik ve post-mitotik süreçlerden meydana gelir. Buna bağlı olarak bitkilerin mitotik ve post-mitotik senesens gösterdiği tanımlanmıştır (Şekil 1). Mitotik senesens (proliferatif senesens) olarak da bilinmektedir ve germline benzeri meristem hücrelerinin mitotik hücre bölünmesine maruz kalma yeteneklerini kaybettikleri zaman meydana gelir. Kültürdeki insan hücreleri ve mayada görülen replikatif senesensin aksine bitkilerdeki mitotik senesens telomer kısalması tarafindan kontrol edilmemektedir. Post-mitotik senesens aktif bir bozulma sürecidir, yapraklar ve çiçek petalleri gibi organlarda meydana gelmektedir [8]. 


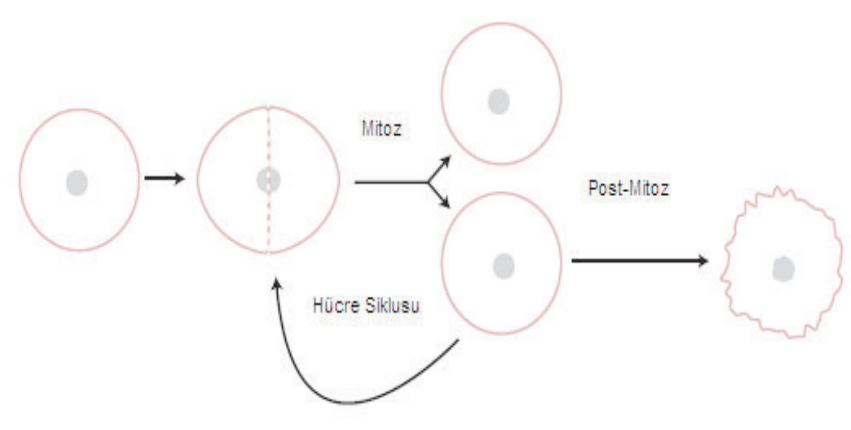

Şekil 1. Bir hücrenin yaşam döngüsünün gösterilmesi. Hücre mitotik ve post-mitotik olmak üzere iki çeşit senesense maruz kalır.

\section{YAPRAK SENESENSI}

Yaprak gelişimi, yaprak taslağının oluşumundan yaprağın genişleme, olgunlaşma ve bozulmasına kadar olan süreci kapsar. Yaprak yaşamında olgunlaşmadan yıpranmaya kadar olan son safha yaprak senesensi olarak adlandırılır. Yaprak sararmas1, yaprak senesensinin görünür bir işaretidir ve yeşil pigment olan klorofilin yıkımı ile sonuçlanırken, fotosentezde de görev alan sarı-kırmızı pigmentler olan karotinoidler parçalanmazlar [9]. Bazı bitki türlerinde, antosiyaninler ve diğer pigmentlerin sentezi, senesens sürecine eşlik eder ve sonbahar yapraklarındaki çeşitli renklerin oluşumuna katkıda bulunurlar. Senesens sırasında klorofil kaybından dolayı, yaprağın fotosentetik kapasitesi ani bir şekilde düşer. Karbohidrat, aminoasit ve diğer moleküllerin yapımı protein, lipid ve nükleik asit (DNA ve RNA) gibi makromoleküllerin yıkımıyla yer değiştirir ve serbest kalan besinler yeni tomurcuklar, genç yapraklar, gelişen meyvalar ve tohumlar gibi bitkinin aktif olarak büyüyen bölgelerine taşınırlar ya da gelecek büyüme sezonu için gövdelerde depo edilirler [10]. Bu nedenle besin geri dönüşüm süreci, bitkinin üreme ve yaşamını sürdürme şansını geliştirdiği için evrimsel yeteneğin bir örneği olarak düşünülmektedir. Bu döngü, büyük yıkım süreci ve besin depolama sonunda ölümle sonuçlanmaktadır [8]. Yaprak senesensi bitki yaprak gelişimindeki önemli evrelerden biri olup, senesens ile ilgili genlerin $(\mathrm{SAG}=$ Senesens ile ilişkili genler $=$ Senescence Associated Genes) anlatımını içermektedir. Senesens sürecinde yaprak hücreleri yapı, metabolizma ve gen anlatımında oldukça düzenli değişikliklere maruz kalırlar [1, 11].

\subsection{Yaprak Senesensi Sırasındaki Hücresel Değişiklikler}

Senesens esnasında bir hücrede meydana gelen yıkım sürecine rağmen, hücre son derece iyi organize edilmiş yapısal değişikliklere maruz kalır. Genel olarak senesens, yaprakların uç bölgelerinde başlar ve vaskular demete yakın hücreler son olarak senesense uğrar. Hücrelerde senesens ile ilgili değişiklikler ilk olarak kloroplastta görülürken, mitokondri ve nukleus senesensin son aşamasına kadar fonksiyonel olarak kalır $[12,13]$. İlk önce genel olarak kloroplastların yapısı bozulur ve sürecin sonunda nukleus yıkılır. Bu süreç ile ilgili en detaylı mikroskobik çalışmalar pirinç koleoptillerinde yapılmıştır. Pirinç koleoptillerindeki tüm mezofil hücreleri senesens sırasında aşağıdaki sırasal olayları paylaşırlar [14]:

y Kloroplast DNA sinın yıkımı,

ע Nukleusun yoğunlaşması, kloroplastın çökmesi, bir kloroplast hedefli fotosentetik enzim olan ribuloz-1,5karboksilaz/oksigenaz'ın yıkımı, tilakoid membranların genişlemesi, osmofilik globullerin sayısı ve boyutunun artması, sitoplazmanın yoğunlaşması,

y Nukleusun organizasyonunun bozulması ve tonoplastın yıkım1,

У Sitoplazmik yapıların tamamen kaybı, hücre çeperi yapısının bozulması, mikroorganizmaların hücrelerarası boşluklara yayılması ve en sonunda hücre içine girmeleri.

Kloroplastlar, bir mezofil hücresindeki proteinlerin $\% 70$ ini içeren organellerdir. Bu yüzden, nukleus gibi diğer hücresel yapılar besin geri dönüşüm sürecini tamamlamak için bozulmamış kalırken, kloroplastların ilk olarak yıkılması anlamlıdir [15].

Senesens sırasında, azot hareketi özümlemeden taşınmaya değişir, fakat mitokondri taşınma sürecine enerji sağlamak için aktif olarak kalır. Mitokondriler ultrastrüktürel bütünlüklerini ve mitokondriyal DNA'lerinin seviyelerini senesens boyunca muhafaza ederler [14]. Protein ve yağların yıkımı da besinlerin senesense uğrayan yapraklardan aktarılmasıyla birlikte yer alır [16]. Senesensde endopeptidazların varlığının fotosentetik proteinlerin devrini kolaylaştırabildiği [17] ve diaçilgliseroltransferazın, senesens sırasında lipidlerin hareketinde bir rol oynadığ bildirilmiştir [18].

Proteinlerin yıkımı çimlenme, farklılaşma, morfogenez ve senesens gibi farklı gelişimsel evrelerde çok önemli bir mekanizmadır [19]. Senesens sirasinda klorofil ve total çözünür proteinler bozulur ve proteolitik aktivite artar [20]. Senesens süresince fotosentez azaldığı zaman, kloroplastlar daha az NADPH ve ATP üretirler. Bununla birlikte, enerji katabolik işlemler için gereklidir ve senesens sırasında yapraklarda solunumun arttığı görülmüştür. Bu artış katabolik işlemler için gerekli olan ATP in temini açısından oldukça 
önemlidir [21]. Pisum sativum L.'de karanlık tarafindan teşvik edilen senesens sırasında mitokondrilerin ve yaprak peroksizomlarının sayısının arttığı rapor edilmiş̧tir [22].

Senesens süresince, besinlerin taşınmasında ve yıkılmasında rol oynayan birçok enzim aktivitelerinin arttığı görülmüştür [23]. Senesense uğrayan bezelye yapraklarının peroksizomlarında $\mathrm{H}_{2} \mathrm{O}_{2}$ seviyesinin ve superoksit dismutaz (SOD) aktivitesinin arttığı, katalaz aktivitesinin ise azaldığı gözlenmiştir. Ek olarak, peroksizomlarda dehidroaskorbat redüktaz (DHAR) aktivitesi artarken, askorbat peroksidaz (APX) ve monodehidroaskorbat redüktaz aktivitesi azalmaktadır [24]. Senesens sirasında peroksizomlardaki manganez-superoksit dismutaz (Mn-SOD) aktivitesi büyük ölçüde artarken, mitokondrilerdeki Mn-SOD aktivitesinin önemli ölçüde azaldığı gözlenmiştir [21]. Yapılan çalışmalarda, yaprak senesensi sırasında, miktarları artan yaklaşık 100 gen Arabidopsis, domates, mısır, tütün, patates, fasulye gibi çeşitli bitki türlerinden izole edilmiştir. $\mathrm{Bu}$ genler proteinaz, nükleaz, lipaz, klorofilaz gibi yıkıcı enzimleri ve glutamat sentetaz gibi azot taşınmasını sağlayan enzimleri kodlamaktadırlar [5, 25, 26].

\subsection{Yaprak Senesensinin Teşviki ve Başlangıcı}

Bitki gelişimi sırasında makromoleküllerin yıkımı ve yapraklardan hücresel komponentlerin taşınması dışsal, çevresel faktörlere bir cevap olarak meydana gelebilir. Bitkiler kötüleşen çevresel durumlara çok hızlı tepki göstermek zorundadırlar ancak hayvanlar gibi hareket yeteneğine sahip olmadıkları için kendileri için daha uygun buldukları bir yere hareket edemezler. Bitkiler cevap olarak kendileri için gerekli olmayan kısımlarını uzaklaştırabilirler. Benzer olarak, N eksikliği, ışık kısıtlamaları ve kuraklık stresi senesens başlangıcını tetikleyerek, erken tohum gelişimine ve indirgenmiş bitki yaşam döngüsüne neden olabilir [27].

Senesensin başlangıcı içsel ve dışsal faktörler tarafindan kontrol edilir. Sıcaklık, kuraklık, besin eksikliği, yetersiz ışık, gölge, karanlık ve patojen enfeksiyonu gibi birçok çevresel ve biyolojik stres senesensi teşvik edebilir. Senesensi etkileyen iç faktörler yaş, bitki büyüme düzenleyicilerinin konsantrasyonları ve reprodüktif büyüme gibi gelişimsel süreçleri içerir [8].

\subsubsection{Yaş}

Doğal yaşamda, bir bitki kaçınılmaz bir şekilde yaprak senesensini teşvik eden olumsuz ve stres faktörü içeren çevrelerle karşı karşıya gelmektedir. Arabidopsis'in de içinde bulunduğu bir çok bitki türünde dışsal streslerin yokluğunda, yaprak senesensi yaşa bağlı olarak meydana gelebilir. Yabani tip Arabidopsis bitkilerinden ve reprodüktif büyümesi geciktirilmiş (geç çiçeklenme mutantları = lateflowering mutants) ya da bozulmuş (erkek ya da dişi steril mutantlar) mutantlardan alınan bireysel yapraklar aynı ömür uzunluğuna sahiptirler [28].

\subsubsection{Sekerler}

Bitkilerde, şeker durumu büyüme ve gelişmeyi idare ederek içsel düzenleyicileri ve çevresel işaretleri ayarlar ve koordine eder [29]. Genellikle bilim adamları şeker konsantrasyonunun yaprak senesensini düzenlediği konusunda hemfikirdirler, ancak yaprak senesensinde yüksek konsantrasyona karşın düşük şeker konsantrasyonlarının etkisi tartışmalıdır. Yapraklar, fotosentez aracılığıyla şekerlerin üretildiği "birincil” bölgelerdir. Fotosentetik aktivite, yaprak senesensi sırasında keskin bir düşüş gösterir, bu aktivite gölge ya da tamamen karanlıkta yaşayan (etiyole) yapraklarda da düşüktür ve bu durumların ikisi de yaprak senesensini teşvik etmektedir. $\mathrm{Bu}$ bulgular, "şekerlerin düşük konsantrasyonu yaprak senesensini teşvik eder" önermesine neden olmaktadır [30, 25].

ע Şeker seviyeleri, senesense uğramayan Arabidopsis ve tütün yapraklarıyla karşılaştırıldığında senesense uğrayan yapraklarda daha yüksektir $[31,32]$.

ע Arabidopsis, tütün ve domates bitkilerindeki yaprakların ekstrasellular alanlarında sukrozun fruktoz ve glukoza yıkımını katalize eden bir enzim olan maya invertaz enziminin anlatımı olduğu zaman, şekerler birikir ve yapraklar erken senesense maruz kalırlar [33, 34].

\subsubsection{Yaprak Senesensinin Düzenlenmesinde Etilenin Rolü}

Etilen senesensi de içeren bitki büyüme ve gelişiminin birçok yönüne karışan gaz halinde bir bitki hormonudur. Etilenin absisyon, fide gelişimi, meyva olgunlaşması, çiçek ve yaprak senesensinde bir role sahip olduğu gösterilmiştir [35]. Etilenin senesens ile ilişkili fizyolojik süreçlerin çoğunu teşvik ettiği belirtilmiştir [36]. Arabidopsis'in etilene duyarsız mutantı olan etr 1 in yapraklarında ve sinyal taşınması eksik olan mutantlarda yaprak senesensi geciktirilmiştir [37]. Antisens teknolojisi yoluyla ACC oksidaz anlatımının dolayısıyla da etilen sentezinin inhibisyonu domatesde yaprak senesensinin gecikmesiyle sonuçlanmıştır [38]. Antisens ACC oksidaz geni içeren transgenik karanfil bitkilerinde, çiçekler düşük klimakterik etilen üretimi göstermişler ve petal senesensi gecikmiştir [39]. Yapraklara dişarıdan etilen uygulanması epinastiye neden olur. Etilen, yapraklarda ve çiçek petallerinde, senesens ile ilgili değişiklikler de meydana getirir. Etilenin bu olaylardaki rolü, gümüş thiosulfat ya da 1-metilsiklopropen gibi etilen inhibitörleri 
kullanılarak gösterilmiştir. Bu inhibitörlerin kullanıldığ kesik çiçek ve yapraklarda senesens önlenmiştir [40]. Tüm bu anlatılanların yanında, temel olarak fazla etilen üreten transgenik Arabidopsis ve domates bitkilerinin yaprakları erken senesens göstermezler, bu durum yalnızca etilenin yaprak senesensini başlatmak için yeterli olmadığ 1 fikrini vermektedir. Yaşa bağlı faktörlerin etilenin düzenlediği yaprak senesensi için gerekli olduğu varsayılmaktadır [8].

\subsubsection{Absisik Asit}

Absisik asit (ABA) bitki büyümesi, gelişimi ve stres cevapları gibi birçok fizyolojik olayı düzenleyen bir bitki hormonudur [41]. İlk çalışmalar dışarıdan ABA uygulamasının kesik yapraklarda senesensi teşvik ettiğini göstermiş̧ir ancak kesik olmayan yapraklarda bu etki daha azdır [8]. Kuraklık, yüksek tuz konsantrasyonu, düşük sıcaklık gibi çevresel stres durumları sıklıkla yaprak senesensini teşvik eder ve bitkiler bu şartlara maruz kalınca yapraklardaki ABA konsantrasyonu artar [42]. Genetik çalışmalar, ABA biyosentezi ya da sinyal yolu eksik çeşitli Arabidopsis mutantlarında değiştirilmiş yaprak senesensi fenotipleri açığa çıktığını göstermektedir [8].

\subsubsection{Salisilik Asit}

Salisilik asit (SA) hemen hemen tüm bitki türleri tarafından üretilen fenolik bir maddedir. Konsantrasyonu türden türe ve dokudan dokuya değişiklik göstermektedir. Bitkilerde, SA patojenlere karşı bitki savunmasına karışan bir sinyal moleküldür ve senesensde de rol oynamaktadır. Suda çözülmüş bir tablet aspirinin kesik çiçeklerin yaşamını uzattığı gözlemlenmiş olmakla beraber, SA uygulaması erken yaprak senesensini teşvik eder. İçsel SA konsantrasyonu senesense uğrayan yapraklarda senesens olmayan yapraklardan 4 kat daha yüksektir. SA-yıkıc1 bir enzimin anlatımının artırılması sonucu yabani tiple karşılaştırıldığında SA in miktarının önemli ölçüde azaldığı Arabidopsis mutantları üretilmiştir. Bu bitkiler, SA sinyal yolu kusurlu Arabidopsis mutantları gibi gecikmiş yaprak senesensi gösterirler [43]. Bu gözlemler SA in yaprak senesensini teşvik ettiğine işaret etmektedirler [8].

\subsubsection{Jasmonik Asit}

Metil jasmonat (MeJA), eterik yağların büyük bir kısmını oluşturur ve öncü maddesi olan Jasmonik Asit (JA) in senesensi teşvik ettiği ilk olarak kesik yulaf yapraklarında gösterilmiştir [44]. Yapraklara meJA uygulaması ile erken senesens başlatılabilmektedir [45]. Son yıllarda bitki gelişiminin farklı evrelerinde de yaygın rol oynadıkları rapor edilmiştir [8]. Yapılan çalışmalar, dışarıdan JA uygulamasının yabani tip Arabidopsis'in kesik ve kesik olmayan yapraklarında erken senesense neden olduğunu işaret etmektedir. Ancak JA duyarsız coil mutantın da erken senesensi teşvik etmekte başarısızdır, bu durum JA sinyal yolunun senesensi teşvik etmek için JA e ihtiyaç duyduğunu akla getirmektedir. Yaprak senesensi sırasında JA biyosentezinde rol oynayan genlerin kademeli olarak anlatımı artmıştır ve senesense uğrayan yapraklarda JA konsantrasyonu senesens olmayan yapraklardan dört kat daha fazladır [46]. Jasmonik asitin teşvik ettiği yaprak sararması gerçektende aktif bir senesens sürecidir. Elde edilen bulgular özel olarak yaprak senesensi sırasında anlatımı artan bir çok genin, ki bunlar senesens ile ilgili genler olarak adlandırılır, sararan yapraklarda da anlatımının olduğunu göstermektedir [8]. Bunun yanında, JA üretimi ve sinyal taşınması eksik bir çok Arabidopsis mutantı gecikmiş yaprak senesensi fenotipi göstermemektedir [46], bu durum JA in senesens de rol oynadığ 1 fikrini reddetmektedir. Muhtemelen, JA in yokluğunda diğer faktörler yaprak senesensini teşvik edebilmektedir [8].

\subsubsection{Brassinosteroidler}

$\mathrm{Bu}$ sınıf bitki steroid hormonları yaprak senesensini de içeren çeşitli gelişimsel programlarda önemli bir rol oynarlar [47]. Yapılan çalışmalar sonucu elde edilen kanıtlar brassinosteroidlerin (BR) yaprak senesensini teşvik edici rolünü ortaya koymaktadır. İlk olarak, 2,4-epi-brassinolide $(e \mathrm{BR})$ in dışsal uygulamasının fasulye yapraklarında [48], salatalık kotiledonlarında [49] ve domates meyvalarında [50] senesensi teşvik ettiği gösterilmiştir. İkinci olarak, BR biyosentezi (örn; det2) ya da BR sinyal yolu (örn; bri1) eksik olan Arabidopsis mutantları gecikmiş yaprak senesensi fenotipi göstermektedirler [51]. bri1 fenotipini baskılayan bir mutasyon belirlenmiştir. Bu mutasyonu içeren bitkiler teşvik edilmiş yaprak senesensi gösterirler [52]. Ayrıca $e \mathrm{BR}$ Arabidopsis'de senesens ile ilişkili genlerin (SAG) bir alt kümesinin anlatımını da teşvik etmektedir [53].

\subsubsection{Yaprak Senesensine Karışan Genlerin Düzenlenmesini İçeren Sinyal Yolakları}

Yaprak senesensine karışan genlerin düzenlenmesinde iş gören en az 4 farklı sinyal yolu tanımlanmaktadır [27]:

1.Sitokinin seviyeleri: Sitokinin seviyesi yapraktaki eşik değerin altına düştüğü zaman senesens başlatılmış olabilir. Sitokinin seviyelerini koruyarak senesensi teşvik eden genlerin transkripsiyonel düzenlenmesi inhibe edilir ve senesens başlangıcı engellenir [27].

2.Gelişen organlardan gelen sinyaller: Gelişen organlar kesildiği zaman, yaprak senesensi baskılanır hatta geri çevrilebilir [54]. Yüksek miktarda etilen 
üreten domates bitkilerinde çiçekler ya da meyva alındığı zaman, muhtemelen gelişen organlardan gelen sinyal yoksunluğundan dolayı yaprak senesensi meydana gelmez [55]. Bu sinyal, sitokinin eşik sinyalinin üstesinden gelemez çünkü yapraklarında IPT (izopentenil transferaz) anlatımı olan transgenik tütün bitkilerinde çiçek ve tohum gelişimi yaprak senesensini teşvik etmemiştir [56]. Bununla birlikte, normal bitkilerde sitokinin seviyeleri gelişen organlardan gelen sinyaller tarafindan etkilenebilir.

3.Etilen: Gecikmiş yaprak senesensi gösteren antisens ve mutant çalışmalar etilenin senesens zamanında değişiklik yaptığını göstermiştir. Artan etilen seviyesi senesensin hızını ve yapraklarda senesens başlangıcını programlar. Etilenin senesens ile ilişkili genleri doğrudan aktive etmediği, ancak muhtemelen diğer sinyal yollarıla genlerin aktivasyonunu değiştirdiği görülür. Etilen fotosenteze karışan genlerin anlatımını baskılamada bir role sahip olabilir [36].

4.Fotosentez ürünleri ve diğer metabolitlerin seviyesi: Arabidopsis ve bazı diğer bitkilerde senesens başlangıcının en erken işareti karbon fiksasyon oranının azalmasıdır ve yaprak maksimum genişlemesine ulaşır ulaşmaz başlar [30]. Sabit karbon kullanımının indirgenmesi ile sonuçlanan fotosentez azalması senesens ile ilişkili genlerin teşvikine neden olan bir sinyal olabilir.

\subsection{9. Çevresel Faktörler ve Yaprak Senesensi}

Senesens sürecini değiştiren diş faktörler genellikle çevreyle ilişkilidir ve stres olarak tanımlanabilirler. Stres, erken senesensin başlangıcına neden olabilir ve bu durum ürün verimini azaltabilir. Dış ortamda; bitkiler soğuk, kuraklık ve UV-B stresi gibi abiyotik stresleri ve mikrobiyal ve fungal saldırı gibi biyotik stresleri içeren sayısız streslere maruz kalırlar. Gün uzunluğu, sıcaklık değişimleri, 1şık akış1, kuraklık, ozon, gölge, yaralanma, UV-B ve patojen enfeksiyonunu içeren çeşitli dişsal faktörler senesensin başlangıcını etkilerler [15].

Bitkiler strese cevap olarak çeşitli savunma mekanizmaları gösterirler. $\mathrm{Bu}$ savunma mekanizmaları erken senesens, pigment sentezi, SA ve JA gibi sinyal moleküllerinin birikimini içerir $[57,58,59]$. Strese karşı oluşan bitki cevapları fotosentezde görev alan proteinler, pigmentler, antioksidanlar ve patojenler ile ilişkili proteinleri kodlayan genler gibi çok sayıda genin transkripsiyonel aktivasyonu ile sonuçlanır [60].

\subsection{Yaprak Senesensinin Genetik Düzenlenmesi}

Diğer bir çok gelişimsel süreç gibi, yaprak senesensi pasif yıkıcı olaylardan ziyade genetik olarak kontrol edilen bir süreçtir ve doğrudan nukleusun kontrolü altındadır [8].
$\mathrm{Bu}$ durum bir su bitkisi olan Elodea' nın yaprakları ile gerçekleştirilen bir deney ile basitce açıklanabilir. Elodea yaprakları hipertonik bir solüsyona yerleştirildiği zaman, mezofil hücreleri aniden çok fazla su kaybederler (Şekil 2). Plazma membranları hücre çeperlerinden ayrılır yani plazmoliz olur. Bazı hücrelerde, protoplast iki eşit parçaya ayrılmıştır, iki parça da protoplast içerirken yalnızca biri nukleus içermektedir. Hücrenin nukleus içeren yarısı beklenen zamanda senesense uğrarken, nukleussuz yarıda senesens ciddi anlamda gecikmiştir. Nukleussuz yarıdaki kloroplastlar yeşildir ve fotosentetik aktivite devam etmektedir [61].

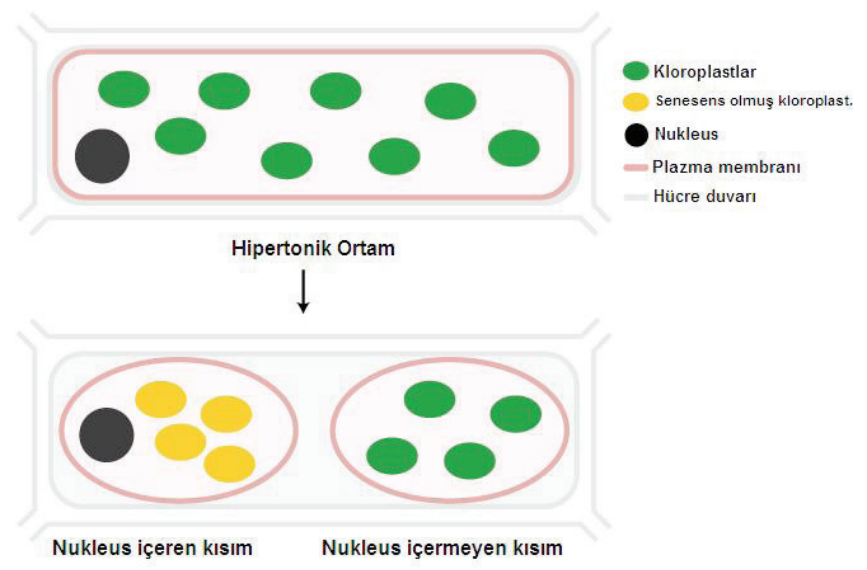

Şekil 2. Senesensin nukleus kontrolünde olduğunu gösteren deney [61]

Yaprak, hücrelerinin programlanmış hücre ölümüne gitmesi için gen anlatımına ihtiyaç duyar. Arabidopsis thaliana'da 2500 kadar gen, bunların 130 dan fazlas1 transkripsiyon faktörlerini kodlar, yaprak senesensi sırasında kopyalanmıştır. Mutant analizleri ve fonksiyonel genomik yaklaşımlar bu genlerin bir çoğunun yaprak senesensinde önemli roller oynadığını ortaya çıkarmıştır [8]. Son yıllarda moleküler biyoloji tekniklerinin yaprak senesensi çalışmalarına uygulanması senesense uğrayan yapraklarda anlatımı artış gösteren genlerin belirlenmesini ve izolasyonunu kolaylaştırmıştır. Bu genlerin analizi ve kodladıkları proteinlerin fonksiyonlarının tanımlanması, senesens sirasında meydana gelen kompleks süreçlerin nasıl bir araya geldiğinin anlaşılmasına izin verecektir. Bugüne kadar, proteazlar ve nükleazlar gibi yıkıcı enzimleri, lipid ve karbonhidrat metabolizmasını kapsayan enzimleri ve azot taşınması ile ilişkili enzimleri kodlayan genler tanımlanmış ve bunlar "senesensi hızlandırıcı genler" olarak 
adlandırılmışlardır. Senesense karışan süreci tamamen anlayabilmek, gelişimsel ve stresle teşvik olan senesens arasındaki farklılıkları belirleyebilmek için senesensle artan genlerin fonksiyonlarını aydınlatmak önemlidir. Senesens sırasında anlatımı değişen genler oksidatif stresten, protein yıkımı, sinyal iletimi, azot, karbon ve fosfor taşınması ile ilgili olayları içerirler [62]. Arabidopsis için tamamlanmış genom arraylerin kullanılabilirliği tanımlanmıştır ve bu durum senesens ile artan genlerin tespitini kolaylaştırmaktadır. Eğer benzer arrayler tahıl türleri için üretilirse, bu durum gen anlatımlarını ve belki farklı bitki türlerindeki senesense karışan süreçleri kıyaslamamıza olanak sağlayacaktır.

\subsection{Yaprak Senesensinin Engellenmesi}

Bitki hormonlarından sitokininler ve poliaminler yaprak senesensinin inhibisyonunda önemli rol oynarlar.

\subsubsection{Yaprak Senesensinde Sitokininlerin Rolü}

Sitokininler tohum gelişimi, fotomorfogenez, kök-gövde farklılaşması, apikal dominansi, hücre bölünmesi ve senesens gibi birçok bitki gelişim süreçlerini düzenler [63, 64]. Yaprak senesensinde sitokininlerin inhibe edici rollerini incelemek ve desteklemek için 3 yaklaşım geliştirilmiştir [65]:

1. Sitokininlerin dışarıdan uygulanması,

2. Senesens sırasında ve öncesinde içsel sitokinin seviyelerinin ölçümü,

3. Transgenik bitkilerde içsel sitokinin üretiminin manipulasyonu.

Arabidopsis thaliana'dan alınan yaprak senesensine özgü SAG12 düzenleyici geni, sitokinin-sentez enzimi olan izopentenil transferazı (IPT) kodlayan genin anlatımını yönetmek için kullanılmıştır. IPT sitokininlerin biyosentezinde ilk ve en önemli basamağı katalizler. Bir yaprak hücresinde senesens başladığı zaman, SAG12 düzenleyicisi $I P T$ gen anlatımını yönetmek (idare etmek) için aktive olur, bu durum sitokinin biyosentezi ile sonuçlanır. İçsel sitokininlerin artışı senesensi bilinmeyen bir mekanizmayla inhibe eder. Senesens inhibe olur olmaz, senesense özgü düzenleyici kısa zamanda inaktif olur, bu durum sitokininlerin aşırı üretimini engeller. Yıkım sonucunda sitokinin seviyesi düştüğü ve yaprak hücreleri senesens olmaya başladığı zaman, senesense özgü düzenleyici daha fazla sitokinin üretmek için yeniden aktif olarak senesensi inhibe eder. Bu döngü oto-düzenleyici (kendinden kontrollü) senesens inhibisyon sistemini oluşturur (Şekil 3).

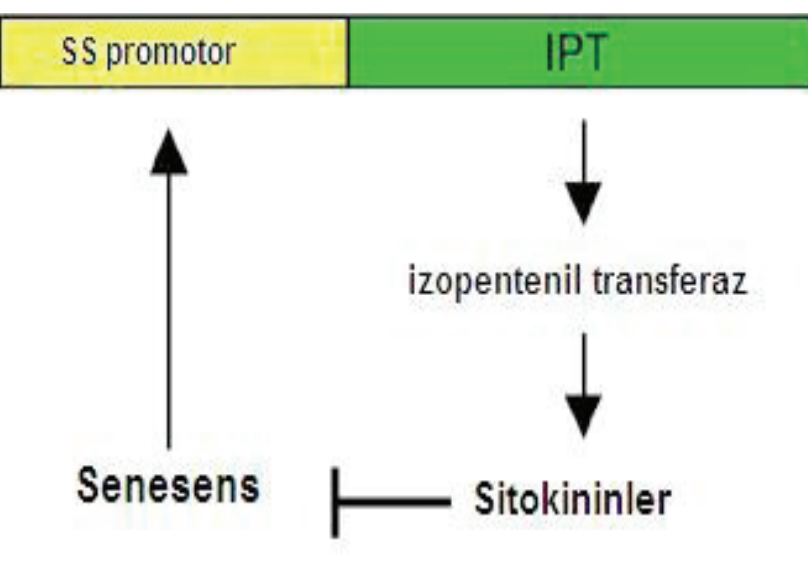

Şekil 3. Sitokininlerin kendinden kontrollü üretimi yoluyla bitki yaşam süresinin uzatılması [15].

Sitokininlerin senesensi geciktirici etkisi yanında, yapılan çalışmalar yüksek konsantrasyonlarda uygulanan Benzil Aminopurinin (BAP) senesensi teşvik ettiğini göstermiştir [66]. Arpa yaprak segmentlerine Kinetin uygulamasının senesens-spesifik kloroplast polipeptidlerinin üretimini zayıflattığı gösterilmiştir [67]. Gören ve Çağ, (2007) bir sitokinin türevi olan Benzil Adenin in dışarıdan uygulanmasının ayçiçeği kotiledonlarında senesensi geciktirdiğini göstermişlerdir [68]. Dışarıdan sitokinin uygulaması, Pisum sativum L. yapraklarında da lipoksigenaz aktivitesini düşürür ve yaprak senesensini geciktirir [69].

\subsubsection{Yaprak Senesensinde Poliaminlerin Rolü}

Putresin, Spermidin ve Spermini içeren poliaminler (PA) hücre çoğalmasında, hücre büyümesinde, proteinler ve nükleik asitlerin sentezinde önemli rol oynayan hücresel elemanlardır [70]. Poliaminlerin bitkilerde post-mitotik senesensi engellemede rol oynadığ 1 , dışarıdan uygulanan PA lerin klorofil kaybı ve membran peroksidasyonunu engelleme yoluyla ve ribonükleaz ve proteaz aktivitelerinin inhibisyonu vasıtasıyla yaprak senesensini engelleyebildiği gösterilmiştir [8, 71]. Bitkilerde S-adenosil metiyonin poliaminlerin ve etilenin biyosentezi için ortak maddedir. Transgenik tütün bitkilerinde etilen üretimi antisens teknolojisi ile bloke edildiği zaman, S-adenosil metiyonin PA biyosentez yoluna yönlendirilir, PA konsantrasyonu büyük ölçüde yükselir ve stresin teşvik ettiği yaprak senesensi geciktirilir [72]. Bunun yanında, etilenin senesensi teşvik ettiği bilinmektedir, bundan dolayı etilen biyosentezinin bloke edilmesi bu transgenik tütün bitkilerinde gecikmiş yaprak senesensi fenotipinin görülmesine en azından kısmen katkıda bulunabilir [8]. 


\section{APOPTOSIS/PROGRAMLANMIŞ HÜCRE ÖLÜMÜ}

Hayvanlarda olduğu gibi bitkilerde de programlanmış hücre ölümü ya da apoptosis, genetik olarak kontrol edilen, hücre farklılaşmasının son safhasıdır. Bazı durumlarda ölürken özel fonksiyonlar kazanırlar (vaskular dokular, lifler gibi) ya da tam tersi olarak hücreler görevlerini tamamladıktan sonra ölürler. Bu tür programlanmış hücre ölümüne gelişimsel hücre ölümü adı verilmektedir ve içsel bir program tarafindan kontrol edilmektedir [73]. Diğer çeşit hücre ölümü ise biyotik ve abiyotik uyarıları içeren farklı çevresel sinyaller ya da patojen saldırıları sonucu oluşur orijinal hücre programında değişiklik yaparlar. Senesens sıklıkla apoptosis ile ilişkilendirilmektedir. Bitkilerdeki programlanmı̧̧ hücre ölümü patojenlere karşı aşırı duyarlılık cevabı ve trakeal elementlerin gelişimini içeren özelleşmiş durumlara yanıt olarak ortaya çıkar. Senesens geciktirilebildiği ve geridönüşümlü olabildiği için programlanmış hücre ölümünden farklı olabilmektedir [74]. Senesens iki aşamada meydana gelir. İlk aşama geri dönüşümlüdür ve hücreler canlılıklarını sürdürürler, ikinci aşama hücre ölümüyle sonuçlanmaktadır [59]. Sitokinin uygulaması sararmış bir yaprak da yeniden yeşillenmeyi teşvik edebilir, protein sentezi ve fotosentetik aktiviteyi yeniden düzenleyebilir [75]. Programlanmış hücre ölümü ise geri dönüşümsüz bir olaydır. Senesensin amacı yaprağın ölümü değildir ancak senesensin bitiminden sonra ölüm meydana gelmektedir [59]. Bu durum programlanmış hücre ölümünün, senesens sürecinin temel olmayan bir bölümü olduğunu göstermektedir.

\section{SONUÇ}

Senesens biyokimyasal ve sitolojik olaylardan meydana gelir. Senesens gelişimsel ve çevresel sinyallerin tetiklemesi ile başlayan, genetik olarak denetlenen bir süreçtir. Senesens sırasında pekçok genin anlatımı azaldığı gibi senesens ile ilişkili genlerin anlatımı ise artmaktadır. Bitki senesensini kontrol eden genlerin anlaşılmasındaki artış gelecekte bir çok ürün türündeki tarımsal sslah için çok önemlidir. Senesensin geciktirilmesi buğday ve misır gibi taneli bitkilerde tane veriminin arttırılmasına yardımcı olur ve herdem yeşil türler bazı tahıl geliştirme programlarında kullanılırlar. Stres tarafindan teşvik edilmiş erken senesens mahsullere zarar verici bir etkiye de sahiptir. Herdem yeşil bitkiler arttırılmış stres direnci gösterebilirler. Ek olarak, hasat sonrası teşvik olmuş senesens tarafindan oluşmuş kalite kaybı yeşil sebzelerin raf ömründe ciddi bir negatif etkiye sahiptir. Sararmanın gecikmesi tedarik zinciri boyunca oluşan zararı azaltacaktır.
Olgunlaşmadan, önce hasat edilen sebzeler, enerji, besin ve hormon kaynaklarındaki ani kesilmeden dolayı oldukça büyük strese maruz kalırlar. Sonuç olarak, Asparagus ve brokoli gibi sebzeler depolarda senesens olurlar ve çok kısa raf ömrüne sahiptirler. Klorofil kaybı, hücre yapısındaki bozulmalar ve son olarak hücre ölümü gibi değişikliklerin çoğu yeşil sebzelerin depolanması sırasında görülürler ve gelişimsel yaprak senesensi sırasında görülen değişikliklerle benzerlik gösterirler.

\section{KAYNAKÇA}

[1] Ok Lim, P., Jung-Kim, H., Nam, G.H. (2007). Leaf Senescence. Annu. Rev. Plant Biol., 58, 115-136.

[2] Liu, L., Zhou, Y., Zhou, G., Ye, R., Zhao, L., Li, X., Lin, Y. (2008). Identification of Early Senescenceassociated genes in Rice Flag Leaves. Plant Mol. Biol., 67, 37-55.

[3] Gregersen, P.L., Culetic, A., Boschian, L., Krupinska, K. (2013). Plant senescence and crop productivity. Plant Mol. Biol., 82, 603-622.

[4] Gully, K., Hander, T., Boller, T., Bartels, S. (2015). Perception of Arabidopsis AtPep peptides, but not bacterial elicitors, accelerates starvationinduced senescence. Front. Plant. Sci., doi:10.3389/ fpls.2015.00014.

[5] He, Y.J. and Gan, S. (2002). A Gene Encoding An Acyl Hydrolase Is Involved in Leaf Senescence in Arabidopsis. Plant Cell, 14, 805-815.

[6] Christiansen, M.W. and Gregersen, P.L. (2014). Members of the barley NAC transcription factor gene family show differential co-rulation with senescenceassociated genes during senescence of flag leaves. $J$. Exp. Bot., 65, 4009-4022.

[7] Penfold, C.A. and Buchanan-Wollaston, V. (2014). Modelling transcriptional networks in leaf senescence. J. Exp. Bot., 65, 3859-3873.

[8] Gan, S. (2003). Mitotic and Postmitotic Senescence in Plants. Sci. Aging Knowl. Environ., 2003 (38), RE7.

[9] Wen, C.H., Lin, S.S., Chu, F.H. (2015). Transcriptome analysis of a subtropical diciduous tree: Autumn leaf senescence gene expression profile of formasan gum. Plant Cell Physiol., 56:163-174.

[10] Avila-Ospina, L., Marmagne, A., Talbotec, J., Krupinska, K., Masclaux-Daubresse, C. (2015). The identification of new cytosolic glutamine synthetase and asparagine synthetase genes in barley and their expression during leaf senescence. . J. Exp. Bot., doi:10.1093/jxb/erv003. 
[11] Lin, M., Pang, C., Fan, S., Song, M., Wei, H., Yu, S. (2015). Global analysis of the Gossypium hirsutum L. Transcriptome during leaf senescence by RNA-seq. BMC Plant Biol., doi:10.1186/s12870-015-0433-5.

[12] Wang, W. (2012). Regulatory RNA-binding proteins in senescence. Ageing Res. Rev., 11, 485-490.

[13] Estiarte, M., Penuelas, J. (2015). Alteration of the phenology of leaf senescence and fall in winter deciduous species by climate change: effects on nutrient proficiency. Global Change Biology, 21,10051017.

[14] Inada, N., Sakai, A., Kuroiwa, H., Kuroiwa, T. (1998). Three-dimensional Analysis of the Senescence Program in Rice (Oryza sativa L.) Coleoptiles. Investigations of Tissues and Cells by Flourescence Microscopy. Planta, 205, 153-164.

[15] Gan, S. and Amasino, R.M. (1997). Making Sense of Senescence. Plant Physiol. 113, 313-319.

[16] Hortensteiner, S. And Feller, U. (2002). Nitrogen Metabolism and Remobilization during Senescence. $J$. Exp. Bot., 53, 927-937.

[17] Yamauchi, Y., Suimoto, T., Sueyoshi, K., Oji, Y., Tanaka, K. (2002). Appearance of Endopeptidases during The Senescence of Cucumber Leaves. Plant Sci., 162, 615-619.

[18] Kaup, M.T., Froese, C.D., Thompson, J.E. (2002). A Role of Diacylglycerol Acyltransferase During Leaf Senescence. Plant Physiol., 129, 1616-1626.

[19] Palma, J.M., Sandalino, L.M., Corpas, F.J., RomeroPuertas, M.C., McCharty, I., Del Rio, L.A. (2002). Plant Proteases, Protein Degradation, and Oxidative Stress: Role of Peroxisomes. Plant. Physiol. Biochem., 40, 521-530.

[20] Reyes-Arribas, T., Barrett, J.E., Huber, D.J., Nell, T.A., Clark, D.G. (2001). Leaf Senescence in A NonYellowing Cultivar of Chrysanthemum (Dendranthema grandiflora). Physiol. Plant., 111, 540-544.

[21] Oleksyn, J., Zytkowiak, R., Reich, P.B., Tjoelker, M.B., and Karolewski, P. (2000). Ontogenetic Patterns of Leaf $\mathrm{CO}_{2}$ Exchange. Morphology and Chemistry in Betula pendula trees. Trees, 14, 271-281.

[22] Del Rio, L.A., Sandalio, L.M., Altomare, D.A., Zilinkas, B.A. (2003). Mitochondrial and Peroxisomal Manganese Superoxide Dismutase: Differential Expression during Leaf Senescence. J.Exp.Bot., 54, 923-933.

[23] Lohman, K.N., Gan, S., John, C.M., Amasino, R. (1994). Molecular Analysis of Natural Leaf Senescence in Arabidopsis thaliana. Physiol. Plant., 92, 322-328.
[24] Kanazawa, S., Sano, S., Koshiba, T., Ushimaru, T. (2000). Changes in Antioxidative Enzymez in Cucumber Cotyledons during Natural Senescence: Comparison with Those during Dark-Induced Senescence. Physiol. Plant., 109, 211-216.

[25] Quirino, B.F., Noh, Y.S., Himelblau, E., Amasino, R.M. (2000). Molecular Aspects of Leaf Senescence. Trends in Plant Science. 5, 278-282.

[26] Thomas, H., Ougham, H.J., Wagstaff, C., Stead, A.D. (2003). Defining Senescence and Death. J. Exp. Bot., 54, 1127-1132.

[27] Buchanan-Wollaston, V. (1997). The Molecular Biology of Leaf Senescence. J. Exp. Bot., 48, 181-199.

[28] Nooden, L.D. and Penney, J.P. (2001). Correlative Controls of Senescence and Plant Death in Arabidopsis thaliana (Brassicaceae). J. Exp. Bot., 52, 2151-2159.

[29] Rolland, F., Moore, B., Sheen, J. (2002). Sugar Sensing and Signaling in Plants. Plant Cell, 14, S185-S205.

[30] Hensel, L.L., Girbic, V., Baumgarten, D.A., Bleecker, A.B. (1993). Developmental and Age-Related Processes That Influence The Longevity and Senescence of Photosynthetic Tissues in Arabidopsis. Plant Cell, 5, 553-564.

[31] Masclaux, C., Valadier, M.H., Brugiere, N., MorotGaudry, J.F., Hirel, B. (2000). Characterization of the sink/source transition in tobacco (Nicotiana tabacum L.) Shoots in Relation to Nitrogen Management and Leaf senescence. Planta, 211, 510-518.

[32] Stessman, D., Miller, A., Spalding, M., Rodermel, S. (2002). Regulation of Photosynthesis During Arabidopsis Leaf Development in Continuous Light. Photosyn. Res., 72, 27-37.

[33] Dickinson, C.D., Altabella, T., Chrispeels, M.J. (1991). Slow-Growth Phenotype of Transgenic Tomato Expressing Apoplastic Invertase. Plant Physiol., 95, 420-425.

[34] Ding, B., Haudenshield, J.S., Willmitzer, L., Lucas, W.J. (1993). Correlation Between Arrested Secondary Plasmodesmal Development and Onset of Accelerated Leaf Senescence in Yeast Acid Invertase Transgenic Tobacco Plants. Plant J., 95, 420-425.

[35] Graham, L.E., Schippers, J.H.M., Dijkwel, P.P., Wagstaff, C. (2012). "Ethylene and senescence process", in Annual Plant Reviews, Vol. 44, ed. Michael T. McNaus, 305-341.

[36] Grbic, V. and Bleecker, A.B. (1995). Ethylene Regulates the Timing of Leaf Senescence in Arabidopsis. Plant J., 8, 595-602.

[37] Li, Z., Peng, J., Wen, X., Guo, H. (2013). Ethylene- 
insensitive 3 is a senescence associated gene that accelerates age-dependent leaf senescence by directly repressing miR164 transcription in Arabidopsis. Plant Cell, 25, 3311-3328.

[38] John, I., Drake, R., Farrell, A., Cooper, W., Lee, P., Horton, P., Grierson, D. (1995). Delayed Leaf Senescence in Ethylene-deficient ACC-oxidase Antisense Tomato Plants- Molecular and Physiological Analysis. Plant J., 7, 483-490.

[39] Savin, K.W., Baudinette, S.C., Graham, M.W., Michael, M.Z., Nugent, G.D., Lu, C.Y., Chandler, S.F., Cornish, E.C. (1995). Antisense ACC Oxidase RNA Delays Carnation Petal Senescence. Hortscience, 30, 970-972.

[40] Srivastava, L.M. (2002). Plant Growth and Development. Hormones and Environment, Academic Press, California, 0-12-660570-X.

[41] Matsuoko, D., Yasufuku, T., Furuya, T., Nanmori, T. (2015). An Abscisic acid inducible Arabidopsis MAPKKK, MAPKKK18 regulates leaf senescence via its kinase activity. Plant. Mol. Biol., doi:10.1007/ s11103-015-0295-0

[42] Finkelstein, R. (2013). Abscisic acid synthesis and response. Arabidopsis book 11:e166 doi:10.1199/ tab.0166

[43] Morris, K., Mackerness, S.A., Page, T., John, C.F., Murphy, A.M., Carr, J.P., Buchanan-Wollaston, V. (2000). Salicylic Acid Has a Role in Regulating Gene Expression during Leaf Senescence. Plant J., 23, 677685.

[44] Ueda, J. and Kato, J. (1980). Isolation and Identification of a Senescence-promoting Substance from Wormwood (Artesemia absinthium L.), Plant Physiol., 66, 246-249.

[45] Springer, A., Acker, G., Bartsch, S., Bauerschmitt, S.R., Reinbothe, C. (2015). Differences in gene expression between natural and artifically induced leaf senescence in barley. J. Plant. Physiol., 176, 180-191.

[46] He, Y., Fukushige, H., Hildebrand, D.F., Gan, S. (2002). Evidence Supporting a Role of Jasmonic Acid in Arabidopsis Leaf Senescence. Plant Physiol., 128, 876-884.

[47] Clouse, S.D. (2002). Brassinosteroids. Plant Counterparts to Animal Steroid Hormones?. Vitam. Horm., 65, 195-223.

[48] He, Y., Xu, R., Zhao, Y. (1996). Enhancement of Senescence by epibrassinolide in Leaves of Mung Bean Seedling. Acta Phytophysiol. Sinica, 22, 58-62.

[49] Zhao, Y., Xu, R., Wo, W. (1990). Antagonist Effect of ABA on Detached Cucumber Cotyledon Senescence Induced by $e$ BR. Chinese Sci. Bull., 35, 928-931.

[50] Vardhini, B.V. and Rao, S.S. (2002). Acceleration of Ripening of Tomato Pericarp Discs by Brassinosteroids. Phytochemistry, 61, 843-847.

[51] Clouse, S.D. and Sasse, J.M. (1998). Brassinosteroids: Essential Regulators of Plant Growth and Development. Annu. Rev. Plant Physiol. Plant Mol. Biol., 49, 427451.

[52] Yin, Y., Wang, Z.Y., Mora-Garcia, S., Li, J., Yoshida, S., Asami, T., Chory, J. (2002). BES1 Accumulates in the Nucleus in Response to Brassinostreoids to Regulate Gene Expression and Promote Stem Elongation. Cell, 109, 181-191.

[53] He, Y., Tang, W., Swain, J.D., Green, A.L., Jack, T.P., Gan, S. (2001). Networking Senescence-Regulating Pathways by Using Arabidopsis Enhancer Trap Lines. Plant Physiol., 126, 707-716.

[54] Crafts-Brandner, S.J. (1991). Non-structural Carbohydrate Metabolism during Leaf Ageing in Tobacco (Nicotiana tabacum). Physiol. Plant., 82, 299305.

[55] Lanahan, M.B., Yen, H.C., Klee, H.J. (1994). The Never Ripe Mutation Blocks Ethylene Perception in Tomato. Plant Cell, 6, 521-530.

[56] Gan, S. and Amasino, R.M. (1995). Inhibition of Leaf Senescence by Autoregulated Production of Cytokinin. Science, 270, 1986-1988.

[57] Parker, J.E. (2000). Signalling in Plant Disease Resistance. In: Molecular Plant Pathology, (Eds. M. Dickinson, and J. Beynon), CRC Press, Sheffield, UK.

[58] Hosch, W.A., Zeldin, E.L., McCown, B.H. (2001). Physiological Significance of Anthocyanins During Autumnal Leaf Senescence. Tree Physiol., 21, 1-8.

[59] Buchanan-Wollaston, V., Earl, S., Harrison, E., Mathas, E., Navabpour, S., Page, T., Pink, D. (2003). The Molecular Analysis of Leaf Senescence- A Genomics Approach. Plant Biotech. J., 1, 3-22.

[60] Shi, H., Reiter, R.J., Tan, D-X., Chan, Z. (2015). INDOLE-3-ACETIC ACID INDUCIBLE 17 positively modulates natural leaf senescence through melatoninmediated pathway in Arabidopsis. J. Pineal. Res., 58, 26-33.

[61] Yoshida, Y. (1961). Nuclear Control of Chloroplat Activity in Elodea Leaf Cells. Protoplasma, 54, 476492.

[62] Pujol, B. (2015). Genes and quantitative genetic variation involved with senescence in cells, organs 
and the whole plant. Front. Plant. Sci., doi:10.3389/ fgene.2015.00057.

[63] Smalle, J., Kurepa, J., Yang, P., Babiychuk, E., Kushnir, S., Durski, A.,Vierstra, D. R. (2002). Cytokinin Growth Responses in Arabidopsis Involve the 26S Proteasome Subunit RPN12. Plant Cell, 14, 17-32.

[64] Eckardt, N.A. (2003). A New Classic of Cytokinin Research: Cytokinin-Deficient Arabidopsis Plants Provide New Insights into Cytokinin Biology. Plant Cell, 15, 2489-2492.

[65] Gan, S. and Amasino, R.M. (1996). Cytokinin in Plant Senescence: From Spray and Pray to Clone and Play. BioEssays, 18, 557-565.

[66] Carimi, F., Terzi, M., De Michele, R., Zottini, M., Schiavo, F.L. (2004). High Levels of The Cytokinin BAP Induce PCD by Accelerating Senescence. Plant Sci., 166, 963-969.

[67] Guera, A. and Sabater, B. (2002). Synthesis of Chloroplast Proteins by Barley Leaf Segments Effects of Senescence Induction and Kinetin Treatment. Acta Botanica Neerlandica, 41, 43-49.

[68] Gören, N. And Çağ, S. (2007). The Effect of Indole3-Acetic Acid and Benzyladenine on Sequential Leaf Senescence on Helianthus annuиs L. Seedlings. Biotechnol. \& Biotechnol. Eq., 21, 322-327.

[69] Liu, X., and Huang, B. (2002). Cytokinin Effects on
Creeping Bentgrass Response to Heat Stress: II. Leaf Senescence and Antioxidant Metabolism. Crop. Sci., 42, 466-472.

[70] Jeevanandam, M. and Petersen, S.R. (2001). Clinical Role of Polyamine Analaysis: Problem and Promise. Curr. Opin. Clin. Nutr. Metab. Care, 385-390.

[71] Cai, G., Sobieszczuk,-Nowicka, E., Aloisi, I., Fattorini, L., Serafani-Fracassini, D., Del Duca, S. (2015). Polyamines are common players in different facets of plant programmed cell death. Aminoacids, 47, 27-44.

[72] Wi, S.J. and Park, K.Y. (2002). Antisense Expression of Carnation cDNA Encoding ACC Synthase or ACC Oxidase Enhances Polyamine Content and Abiotic Stress Tolerance in Transgenic Tobacco Plants. Mol. Cells, 13, 209-220.

[73] Wu, X., Kuai, B., Jia, J., Jing, H. (2012). Regulation of leaf senescence and crop genetic improvement. J. Int. Plant Biol., 54, 936-952.

[74] Del Duca, S., Serafini-Fracassini, D., Cai, G. (2014). Senescence and programmed cell death in plants: polyamine action mediated by transglutaminase. Front. Plant Sci., 5, 1-16

[75] Ventarakayappa, T., Fletcher R.A., Thompson, J.E. (1984). Retardation and reversal of senescence in beanleaves by benzyladenine and decapitation, Plant Cell Physiol., 25, 407-418 